\title{
Primary Teachers' Perceptions of CLIL Implementation in Spain
}

\author{
José María Campillo $^{1}$, Raquel Sánchez ${ }^{1} \&$ Pedro Miralles ${ }^{1}$ \\ ${ }^{1}$ Faculty of Education, Social Science Teaching Department, University of Murcia, Murcia, Spain \\ Correspondence: José María Campillo, Social Science Teaching Department, University of Murcia, Murcia, \\ Spain
}

Received: January 30, 2019 Accepted: March 14, 2019 Online Published: March 17, 2019

doi: 10.5539/elt.v12n4p149 URL: https://doi.org/10.5539/elt.v12n4p149

\begin{abstract}
CLIL (Content and Language Integrated Learning) has been one of the major innovations that has been implemented in Spain in the last decades and many questions have arisen in relation to its effectiveness. The aim of this article is to report primary teachers' perceptions of the most relevant aspects of CLIL teaching of Science and Social Science in Primary Education in the Region of Murcia. Their perceptions of this integrated approach are crucial to meet their needs, coordinate their efforts and develop good practice. Results from this research emphasize an extensive application of CLIL methodological guidelines and the use of a wide range of tools when evaluating learners' competences. Additionally, they have expressed their satisfaction with language assistants when motivating pupils and fostering their oral skills and intercultural awareness. However, CLIL teachers believe Public Administration should provide more resources, further training and enhanced coordination to improve the quality of education under this paradigm.
\end{abstract}

Keywords: CLIL, primary education, science, evaluation

\section{Introduction}

\subsection{CLIL Implementation}

The teaching approach known as CLIL appeared in the European educational framework in the last decade of the twentieth century as a result of research into foreign language learning and teaching processes. Supported by European policies in favor of multilingualism, such as the White Paper in 1995, which highlighted the need to learn two foreign languages in addition to one's mother tongue, or the Common European Framework of Reference for Languages of the Council of Europe in 2001 which defined language proficiency in six levels, A1 to $\mathrm{C} 2$ in order to specify the progressive mastery of a foreign language (henceforth, FL), CLIL has been seen as one of the most striking innovations in Europe. Its inclusion in the main European education systems has supposed a change of paradigm for foreign language teaching, which implies, necessarily, the development of innovative methodologies in these European education settings, namely ÉMILE (Enseignment de matières par intégration d'une langue étrangère) in French, AICLE (Aprendizaje integrado de contenidos y lenguas extranjeras) in Spanish or Bilingualer Sachfachunterricht in German (Breidbach \& Viebrock, 2012). This educational paradigm is based on the teaching of one or several content-based subjects through a FL, which makes that second language the main communicative tool in the classroom. Its dual nature is, obviously, the main aspect that singularizes this approach because it promotes the learning of different NLA, such as Mathematics, Geography or History through a language other than learners' mother tongue. One key aspect is that language is presented in simulated real-life situations in which learners can develop their communicative language competences, multilingual interests and intercultural skills.

As it concentrates on the acquisition of language skills and content-subject competencies, the distributive programming of FL and NLA contents has to be harmonious so as to avoid any lack of balance: «CLIL is not language teaching enhanced by a wider range of content. Neither is it content teaching translated in a different language (code) from the mother tongue» (Coyle, Hood, \& Marsh, 2010: 2). To better understand what this paradigm is and to identify the components that comprise it, Coyle (1999) described four core elements underpinning CLIL:

- Content: Related to the knowledge on the NLA and some cross-curricular themes.

- Communication: To enable both teacher and learners to construct an understanding of the NLA through the use of a FL. 
- Cognition: Related to the thinking processes involved during the comprehension and assimilation of new contents.

- Culture: To establish mechanisms to enhance intercultural awareness between different cultures and languages.

Therefore, CLIL is about providing opportunities and tools for all learners to gain the skills, knowledge and competences required to carry out a range of tasks with a view to enhancing quality of learning achievements in both FL and NLA (Lasagabaster, 2008; Heras \& Lasagabaster, 2015). In order to articulate these main aspects, teaching practice is essential to select and organize learning goals, promote exchanges of information in L2 and provide a motivating and supporting environment (Lasagabaster, 2011). For this reason, it is important to gain insight into teachers' attitudes towards this approach and their adherence to CLIL guidelines.

\subsection{History of CLIL in Spain}

The promotion of FL learning in addition to the mother tongue has materialized in Spain in the last decades through different curricular proposals in agreement with the idiosyncrasies of each autonomous community (Bruton, 2011). The emergence of successful CLIL programs throughout Europe has accelerated the planning of public policies in Spain, focusing on promoting bilingualism, or even multilingualism, and on implementing educational programs aimed at legitimizing this innovation. Consequently, these political initiatives have generated a new dynamic for FL teaching, which has implied the effective implementation of a paradigmatic change under this approach. This encompasses the coexistence of different multilingual educational scenarios, classified by Muñoz Lahoz and Navés (2007) in three large groups. First, the Spanish-British integrated curricular projects, organized by the Ministry of Education and the British Council in favor of learning English as a FL and established in ten autonomous communities in 87 primary schools and in 53 secondary schools. Second, the multilingual programs in the monolingual autonomous communities, whose mother tongue is Spanish, and which are based mainly on the teaching of one or several NLA through L2 as the vehicular language under CLIL. Finally, we find multilingual education systems introduced in communities with co-official languages such as Catalan, Galician or Basque whose experiences in bilingual education are more extensive than in the rest of Spain due to their distinctive features. This classification helps us to better understand the complex nature of bilingual education in Spain as well as to describe the educational reality of a specific autonomous community based on the contextual indicators described above. Thus, this description serves to determine that, in the current context where bilingual education has been established in the Region of Murcia, the first two scenarios above converge in most primary schools. It is important therefore to ensure that these scenarios already developed are applied in such a way as to secure the achievement of multilingual goals.

\subsection{Bilingual Education in the Region of Murcia}

As we have described, the Region of Murcia has joined the initiative to promote the learning of several FL in compulsory educational stages, something which was already promoted some decades ago by other Spanish autonomous communities through various programs and models (Fernández Fontecha, 2009). In relation to the first bilingual scenario, the first steps in this direction began in the wake of the Collaboration Agreement promoted by the Ministry of Education and the British Council February $1^{\text {st }}, 1996$, which that allowed the accession of two primary schools in Murcia to a bilingual curricular project: CEIP Infante D. Juan Manuel from Murcia and CEIP José María Lapuerta from Cartagena. These schools developed an integrated bilingual curriculum for students to acquire academic certificates in both languages and to continue their studies after finishing compulsory Secondary Education in either of the two countries. In addition, the aforementioned agreement promotes research on different models and implementations under this approach. Currently, a high school from the Region of Murcia has also joined the project, IES Los Molinos from Cartagena. With regard to the second scenario described above, the Ministry of Education of the Murcia Regional government established the program called "Bilingual Schools from the Region of Murcia" (CBM), through the Order of 25 May, 2009, which sought to contribute to the objective set by the European Council of Lisbon in 2000 in favor of the promotion of FLL, the improvement of communicative competence in English and the intercultural development in the Murcia classrooms. This legislative provision initially regulated the network of bilingual primary schools in the Region of Murcia, which freely chose whether or not to participate, and increased pupils' exposure to L2 by up to one third of their school time. In addition, it presented different access modalities -initial, intermediate or advanced- according to the number of NLA taught in English, namely Science, Art and Physical Education. Once primary schools joined, their implementation was gradual from the first year of Primary Education until completing the stage. Subsequently, successive modifications of this order have introduced different variations to the initial program, such as the inclusion of new NLA in the program - Natural Sciences, Social Sciences, Mathematics, Religion or Social and Civic Values - 
through the Resolution of 2 June, 2014, or the possibility of replacing an NLA taken from first to third grade of Primary Education by an additional subject from fourth grade onwards, through the Orders of 15 June, 2015, and 3 June, 2016. These changes aim to adapt bilingual education to the specific educational context where it is carried out, providing the opportunity to choose from several options according to the peculiarities of each school. With regard to the degree of implementation of these programs, it can be concluded that it has gradually grown since in the academic year 17/18, 356 primary schools of the 521 schools that make up the network of primary schools in the Region of Murcia were teaching CLIL. These schools represent $68.3 \%$, although there are differences between state and private ones, because only $61.3 \%$ of the former are bilingual compared to $91.6 \%$ of the latter. Consequently, there is a growing trend in favor of bilingual education in this autonomous community that will progressively incorporate the other primary schools in the near future, in accordance with the policy set by the educational administration of Murcia in its strategy "+ Languages". The final goal pursued by this initiative is that all students in the Region of Murcia are able to access bilingual education in 2019.

Among the necessary conditions to effectively carry out CLIL, the aforementioned norm points to the use of didactic materials adapted to this approach not only as resources to be taken into account in the teaching program, but also as relevant factors to keep coordination active (Guerrini, 2009). These materials are often prepared by the teaching staff assigned to the bilingual programs in collaboration with the rest of the teaching staff, such as FL teachers and / or language assistants. Likewise, the legislative provisions in this regard reflect the need to promote active and dynamic methodologies in the classroom that favor pupils' involvement, meaningful communicative exchanges in English, as well as the development of interpersonal relationships in class, as reflected in studies under this approach (Mehisto, Marsh, \& Frigols, 2008; Meyer, 2010). In this sense, these methodological initiatives seek to distance themselves from traditionally rigid didactic models in order to promote a more collaborative and flexible methodology that reinforces the role of the students as protagonists of their own learning and so guarantee and increase their participation and involvement throughout the years (Zhang, 2010). This task-based learning focuses on the use of authentic language and permits considerable flexibility for pupils' needs to be attended to. The organization of students into small groups as an alternative to individual work means that most tasks proposed can be solved in a more coordinated and effective way while, at the same time, increasing the autonomy of students in the classroom. In addition, the use of a FL does not affect pupils' degree of motivation compared to similar groups of students whose vehicular language is their mother tongue (Seikkula-Leino, 2007). As a consequence, these methodological initiatives foster an agile comprehension of the contents, a quick exchange of ideas and an effective performance of programmed group tasks while helping to improve the levels of self-esteem and personal image. In line with the above, the variety of groupings promoted in CLIL lessons not only favors the practice of interactive tasks based on the consensual realization of activities in a FL but also the application and development of certain learning strategies by the students that are basic to organizing and distributing the contents of the NLA and, therefore, structuring their learning processes. For this purpose, CLIL teachers must plan a didactic sequence adapted to the pupils' needs and one that is effective to make them progress in the achievement of the proposed objectives (Martínez Pastor, 2011).

\section{Method}

This study is part of a research project developed at the University of Murcia that aims to analyze the application of CLIL in the bilingual program in the areas of Science and Social Science in the 1st and 2nd year of Primary Education in the Region of Murcia. Its main aim has been to gather information about real teaching practice in the Murcia bilingual educational context during the academic year 2014-15 in order to deepen the understanding of educational processes (Bisquerra Alzina, 2004). According to Tapia (2000), educational research allows us to examine how a phenomenon is conceived and manifested and the elements that make it up - in this case teaching practice in bilingual programs. Indeed, Perrenoud (2001) states that the description of the working conditions at school is the starting point for any possible innovation, so educational research should be framed in a social environment in which the subjective perspective of the professionals of the educational community is taken into account to interpret the relevance of the didactic elements studied, and, consequently, to be able to transform them in the future. In addition, bearing in mind that the first two years of primary education are fundamental for learning languages and acquiring literacy skills, this study has focused on this crucial two-year period to describe the conditions under which CLIL teachers work. In particular, we have focused on the distinctive features that define teachers' educational programming of the subjects of Social Science in the first grade and Science in the second grade of Primary Education in relation to certain aspects: coordination with language assistants, methodological guidelines adopted, use of evaluation instruments and reviewable conditions in these programs. To accomplish this, a quantitative and qualitative integration methodology has been used in this study in order to delve more meaningfully into the subject in question, so deepening and articulating the knowledge derived from 
this study and thus develop a clearer understanding of the subject that concerns us. For this purpose, adapted data collection tools were implemented to gather quantitative and qualitative information on teachers' knowledge, attitudes and practices.

\subsection{Participants}

All 223 schools in the Region of Murcia in the academic year 2015-2016 were considered when selecting the sample of CLIL teachers and the main data were taken from the databases of the Regional Ministry of Education. 129 participants from 114 primary schools completed the questionnaire, representing 51.1 percent of bilingual schools. Of these 129 teachers, 99 worked in state schools and thirty worked in private schools that are state subsidized. According to CEFR levels (Common European Framework of Reference for Languages) the average profile of the CLIL teacher who has collaborated in this study was state teacher of Science with a B2 level of English, who has been involved in education for ten years and in bilingual education programs for three years. In addition, 20 of the participants held a higher degree in Bilingual Education and 28 had a higher level than B2 (25 had $\mathrm{C} 1$ and three $\mathrm{C} 2$ ). Of the 12 participants in the discussion forum, five worked in state schools and seven in private schools.

\subsection{Instruments}

The data collection tools used in this study were the semi-structured questionnaire and the discussion forum, both of which are widely used in social science research. The questionnaire is defined, as Tapia (2000) states, as a standardized instrument that translates and synthesizes research problems and that must meet two essential requirements: validity and reliability. Both features according to Bravo, Eisman \& Hernández (1998) determine the degree of credibility of the investigation; while reliability focuses on replicability, validity focuses on accuracy and the ability to generalize results. As Ramos, Palacín and Márquez (2004) describe, the application of the questionnaire facilitates the systematic transfer of data and the possibility of incorporating control mechanisms through filter questions that allow the representation of the different empirical work conditions developed by the respondents. The semi-structured questionnaire was elaborated on an ad hoc basis and its validation underwent several revisions during the development of this study in order to take into account both technical opinions of a group of expert professors of the University of Murcia and those of a group of bilingual teachers. Its structure is organized into different questions rated on a 5-point Likert scale linked both to teachers' professional profile and to CLIL implementation. Both open-ended and close-ended questions are divided into two sections: in the first one teachers are asked about their professional situation, while in the second one they are invited to rate and make comments about CLIL teaching practice. The second instrument of this study consists of six questions based on elements associated with the teaching practice, such as the use of CLIL resources and the detection of needs linked to the didactic application of the program in the classrooms. Its more open nature provides the opportunity for teachers to provide more extensive opinions about bilingual practice in CLIL lessons while complementing those issued in the other section of this study. The following questions were posed to organize the discussion forum: (a) What positive results have been achieved through direct collaboration between CLIL teachers and language assistants? (b) What professional training is necessary for language assistants under this approach? (c) Do you think the exchange of methodological and educational good practice among CLIL teachers is particularly useful? (d) Should CLIL teachers be better coordinated with local authorities and institutions? (e) Which evaluation tools are the most widely used in CLIL teaching? (f) Which significant improvements are required to optimize this approach?

\subsection{Procedures}

Data from the first instrument were received telematically after informing the respondents about the aim of this study and the instructions to complete the questionnaire. Regarding the discussion forum, the data was obtained in three private meetings with teachers with a duration of approximately 45 minutes each. The data collected was analyzed with SPSS version 23.

\section{Results}

In this section, we offer a detailed analysis of the opinions expressed by the participants of this study about the fundamental aspects that define CLIL implementation in primary schools in the Region of Murcia in Spain.

\subsection{Language Assistants}

From the questionnaire responses, coordination with language assistants can be considered as profitable since most of the answers issued are located between the values 3 and 4. Likewise, a greater satisfaction is shown with Anglo-Saxon natives' support in some aspects like motivation or development of pupils' oral and written skills and intercultural awareness in class. 
Table 1. Level of satisfaction with language assistants' collaboration

\begin{tabular}{|c|c|c|c|c|c|c|c|c|c|}
\hline & $\mathrm{AV}$ & SD & U Mann-Whitney & Z & $\mathrm{p}$ & $\begin{array}{l}\mathrm{H} \\
\text { Kruskal- Wa }\end{array}$ & & $\mathrm{gl}$ & p. \\
\hline \multirow{2}{*}{$\begin{array}{l}\text { Intercultural } \\
\text { awareness }\end{array}$} & & & & & & Experience & 8.134 & 3 & $<.043^{*}$ \\
\hline & 3.59 & 1.54 & 1173.50 & -1.821 & .069 & Training & 2.658 & 4 & .617 \\
\hline \multirow{2}{*}{$\begin{array}{l}\text { Written } \\
\text { skills }\end{array}$} & & & & & & Experience & 10.057 & 3 & $<.018^{*}$ \\
\hline & 3.26 & 1.43 & 1260.50 & -1.288 & .198 & Training & 3.679 & 4 & .451 \\
\hline
\end{tabular}

There are significant differences according to CLIL teachers' years of experience, as the subgroups with longer teaching experience claim to be more satisfied with language assistants when motivating learners and fostering their written skills and intercultural awareness in CLIL lessons. In the same line, teachers' responses in the discussion forum emphasized the increase of the motivation on the part of school children because of language assistants' collaboration during CLIL lessons. Notwithstanding, results from both instruments show that more pedagogical training should be required for language assistants to work with children.

\subsection{CLIL Methodological Guidelines}

According to responses to the questionnaire, the most frequently followed methodological guidelines in the Murcia classrooms are those that enhance interculturality, activation of pupils' prior knowledge and the use of ICT and other resources in the classroom. In statistical terms, the Mann-Whitney U test reveals significant differences between teachers working in state schools and those who work in private schools, since the former use a greater variety of CLIL techniques and strategies in their teaching practice more frequently than the latter.

Table 2. Frequency of use of CLIL methodological guidelines

\begin{tabular}{|c|c|c|c|c|c|c|c|c|c|}
\hline & AV & SD & U Mann-Whitney & Z & p. & $\begin{array}{l}\mathrm{H} \\
\text { Kruskal- Wi }\end{array}$ & & gl & p. \\
\hline \multirow{2}{*}{$\begin{array}{l}\text { Intercultural } \\
\text { awareness }\end{array}$} & & & & & & Experience & 4.732 & 3 & .192 \\
\hline & 4.26 & 1.01 & 897.50 & -3.612 & $<.000^{*}$ & Training & 3.340 & 4 & .503 \\
\hline \multirow{2}{*}{$\begin{array}{l}\text { Recalling } \\
\text { experiences }\end{array}$} & & & & & & Experience & 3.618 & 3 & .306 \\
\hline & 4.13 & 1.04 & 1101.000 & -2.305 & $<.021^{*}$ & Training & .174 & 4 & .996 \\
\hline
\end{tabular}

Additionally, teachers have expressed their interest in further sharing best practices on the aforementioned issues to become better professionals and create a better working environment. According to their views, more efforts should also be made by local authorities to promote good practice among CLIL teachers in order to cope with the challenges of harmonizing methodological guidelines when teaching these content-based subjects.

\subsection{Evaluation Instruments}

According to the results of the questionnaire, the most commonly used tools to measure pupils' learning are class assignments followed by written exams, oral presentations and projects. The use of a variety of resources to evaluate pupils guarantees a more accurate measurement of their results and the teaching and learning processes that take place in the classroom. There are differences in the frequency of use of written exams as an instrument to evaluate students in Science, since state school teachers use them significantly more than private school teachers in a more thorough and accurate way during CLIL lessons with a view to the development of each pupil's skills and key competences. These responses are in line with the ones expressed in the discussion forum. 
Table 3. Most frequently used evaluation instruments in CLIL lessons

\begin{tabular}{|c|c|c|c|c|c|c|c|c|c|}
\hline & AV & SD & U Mann-Whitney & Z & $\mathrm{p}$ & $\begin{array}{l}\mathrm{H} \\
\text { Kruskal- W }\end{array}$ & & gl & p. \\
\hline \multirow{2}{*}{$\begin{array}{l}\text { Intercultural } \\
\text { awareness }\end{array}$} & & & & & & Experience & 8.134 & 3 & $<.043^{*}$ \\
\hline & 3.59 & 1.54 & 1173.50 & -1.821 & .069 & Training & 2.658 & 4 & .617 \\
\hline \multirow{2}{*}{$\begin{array}{l}\text { Written } \\
\text { skills }\end{array}$} & & & & & & Experience & 10.057 & 3 & $<.018^{*}$ \\
\hline & 3.26 & 1.43 & 1260.50 & -1.288 & .198 & Training & 3.679 & 4 & .451 \\
\hline
\end{tabular}

\subsection{Reviewable Conditions}

The responses from the questionnaire clearly indicate that there are some conditions that should be improved, such as the availability of resources, CLIL training or school coordination with other members of the educational community. Significant differences are found among the subgroups analyzed, since less well-trained teachers demand significantly more training than the rest of the subgroups examined.

Table 4. Reviewable conditions under CLIL

\begin{tabular}{|c|c|c|c|c|c|c|c|c|c|}
\hline & \multirow[b]{2}{*}{ AV } & \multirow[b]{2}{*}{ SD } & \multirow[b]{2}{*}{ U Mann-Whitney } & \multirow[b]{2}{*}{ Z } & \multirow{2}{*}{ p. } & \multicolumn{3}{|l|}{$\mathrm{H}$} & \multirow[b]{2}{*}{ p. } \\
\hline & & & & & & Kruskal- Wa & & $\mathrm{gl}$ & \\
\hline \multirow{2}{*}{ More training } & \multirow{2}{*}{3.44} & \multirow{2}{*}{1.24} & \multirow{2}{*}{1468.50} & \multirow{2}{*}{-0.97} & \multirow{2}{*}{.923} & Experience & 3.214 & 4 & .523 \\
\hline & & & & & & Training & 9.557 & 4 & $<.049^{*}$ \\
\hline
\end{tabular}

In the same way, teachers' responses in the discussion forum highlighted the need to improve training under this approach.

\section{Discussion}

The results presented in the previous section reflect significant differences among the participating teachers in this study in all areas of research. First, we find differences in the appreciation of the work of language assistants among the subgroups of teachers with different years of teaching experience. Anglo-Saxon natives' collaboration in the classroom is more valued by teachers with longer teaching experience due to their help in increasing motivation and interculturality in class. They also value their efforts to promote written skills in CLIL lessons when basic strategies for understanding written texts or reflective observation of written productions are promoted.

In relation to the methodology adopted by the teaching staff assigned to these programs, there is a frequent use of various methodological strategies and techniques associated with this approach (Dalton-Puffer, 2007; Viebrock, 2012), although significant differences in their frequency of application have been identified, since private school teachers do not follow these guidelines as often as state school teachers. In this sense, therefore more research is needed to ascertain whether it is necessary to make methodological changes in CLIL teaching so that a better harmonization of methodology at public and private schools could be achieved.

In terms of evaluation, NLA tasks are considered to be an ideal instrument to measure the acquisition of Science and Social Science content, which marks a major turning point in the teaching of NLA, since until now written tests have been used as the main assessment tool in these subjects. In this sense, more experienced teachers advocate a wider variety of evaluative resources, since they significantly use a wider range of instruments in accordance with the CLIL guidelines in this regard. In relation to the reviewable conditions under this approach, teachers demand a greater amount of resources, training and coordination from the educational administrations. In addition, there are statistically significant differences in the demand for training among less well-trained teachers in CLIL. Thus, all these demands should be taken into consideration in order to improve the implementation of these programs in the Region of Murcia. Moreover, more research is needed into similar initiatives to establish what conditions can improve CLIL teaching practice. In this sense, not only teachers but also pupils and parents should be actively involved in the process of joint reflection on ways to enhance the effectiveness of these programs. 
In summary, the development of professional competences that streamline the teaching and learning processes according to CLIL principles is fundamental to guarantee quality education in this context (Pavón Vázquez \& Ellison, 2018). Consequently, it is necessary to improve teachers' training in this new paradigm in order to adjust their teaching practice to CLIL core principles more accurately (Lova Mellado, Bolarín Martínez \& Porto Currás, 2013). For this reason, it is convenient to attend more intensively to those groups of teachers that present more difficulties when carrying out these programs, such as teachers with shorter experience or less well-trained in CLIL, among others. In this sense, a greater endowment of both human and material resources, as well as better training and coordination by educational administrations, would imply a boost for the improvement of CLIL teaching practice in this context.

\section{Acknowledgements}

Stephen Hasler- Proof-reader.

Alfonso Robles Fernández- Writing assistant

Michael Palmer- Provided language help.

\section{References}

Bisquerra Alzina, R. (Ed.) (2004). Metodología de la investigación educative (Vol. 1). Madrid: La Muralla.

Bravo, M. P. C., Eisman, L. B., \& Pina, F. H. (1998). Métodos de investigación en psicopedagogía. Madrid: McGraw-Hill.

Breidbach, S., \& Viebrock, B. (2012). CLIL in Germany: Results from recent research in a contested field of education. International CLIL Research Journal, 1(4), 5-16.

Bruton, A. (2011). Is CLIL so beneficial, or just selective? Re-evaluating some of the research. System, 39(4), 523-532. https://doi.org/10.1016/j.system.2011.08.002

Coyle, D. (1999). Theory and planning for effective classrooms: Supporting students in content and language integrated learning contexts. En J. Masih (Ed.), Learning Through a Foreign Language: Models, Methods and Outcomes (pp. 46-62). London: CILT Publications.

Coyle, D., Hood, P., \& Marsh, D. (2010). CLIL. Cambridge, England: Cambridge University Press.

Dalton-Puffer, C. (2007). Discourse in content and language integrated learning (CLIL) classrooms. Amsterdam, the Netherlands: John Benjamins Publishing. https://doi.org/10.1075/1llt.20

Fernández Fontecha, A. (2009). Spanish CLIL: Research and official actions. In Y. Ruiz de Zarobe, \& R. M. Jiménez Catalán (Eds.), Content and Language Integrated Learning. Evidence from research in Europe (pp. 3-21). Bristol: Multilingual Matters. https://doi.org/10.21832/9781847691675-004

Guerrini, M. (2009). CLIL materials as scaffolds to learning. In D. Marsh, P. Mehisto, D. Wolff, R. Aliaga, T. Asikainen, M. Frigols-Martin, S. Hughes, \& G. Langé (Eds.), CLIL practice: Perspectives from the field. Jyväskylä: University of Jyväskylä.

Heras, A., \& Lasagabaster, D. (2015). The impact of CLIL on affective factors and vocabulary learning. Language Teaching Research, 19(1), 70-88. https://doi.org/10.1177/1362168814541736

Lasagabaster, D. (2008). Foreign language competence in content and language integrated courses. The Open Applied Linguistics Journal, 1(1), 30-41. https://doi.org/10.2174/1874913500801010030

Lasagabaster, D. (2011). English achievement and student motivation in CLIL and EFL settings. Innovation in language Learning and Teaching, 5(1), 3-18. https://doi.org/10.1080/17501229.2010.519030

Lova Mellado, M., Bolarín Martínez, M.J. y Porto Currás, M. (2013). Programas bilingües en Educación Primaria: valoraciones de docentes. Porta Linguarum: Revista Internacional de Didáctica de las lenguas extranjeras, 20, 253-268. https://doi.org/10481/22306

Mehisto, P., Marsh, D., \& Frigols, M. J. (2008). Uncovering CLIL. Oxford: Macmillan.

Meyer, O. (2010). Towards quality-CLIL: Successful planning and teaching strategies. Pulse, 33, 11-29.

Muñoz Lahoz, C. \& Navés, T. (2007). Windows on CLIL in Spain. In A. Maljers, D. Marsh, \& D. Wolff, (Eds.), Windows on CLIL (pp. 160-165). The Hague, the Netherlands: European Centre for Modern Languages.

Martínez Pastor, M. R. (2011). CLIL and cooperative learning. Encuentro, 20, 109-118.

Pavón Vázquez, V., \& Ellison, M. (2018). Examining teacher roles and competences in Content and Language Integrated Learning (CLIL). Linguarum Arena: Revista de Estudos em Didáctica de Linguas da 
Universidade do Porto, 4, 65-78.

Perrenoud, P. (2001). La formación de los docentes en el siglo XXI. Revista de Tecnología Educativa, 14(3), 503-523.

Ramos, A. M. G., Palacín, F. F., \& Márquez, M. M. (2004). Diseño de encuesta sobre las metodologías y la actividad científica de los equipos de investigación. Metodología de encuestas, 6(2), 133-145.

Seikkula-Leino, J. (2007). CLIL learning: Achievement levels and affective factors. Language and Education, 21(4), 328-341. https://doi.org/10.2167/le635.0

Siguán, M. (2001). Bilingüismo y lenguas en contacto. Madrid: Alianza.

Tapia, M. (2000). Metodología de investigación. Santiago, Chile: Persa.

Viebrock, B. (2012). The situation in the CLIL classroom is quite different -or is it? Teachers' mindsets, methodological competences and teaching habits. In D. Marsh, \& O. Meyer (Eds.), Quality Interfaces: Examining Evidence \& Exploring Solutions in CLIL (pp. 78-90). Eichstaett: Eichstaett Academic Press.

Zhang, Y. (2010). Cooperative language learning and foreign language learning and teaching. Journal of Language Teaching and Research, 1(1), 81-83. https://doi.org/10.4304/j1tr.1.1.81-83

\section{Copyrights}

Copyright for this article is retained by the author(s), with first publication rights granted to the journal.

This is an open-access article distributed under the terms and conditions of the Creative Commons Attribution license (http://creativecommons.org/licenses/by/4.0/). 